\title{
UN CUADERNO DE APRENDER ARABE, EN ELCHE, DE 1768
}

\author{
Por \\ MIKEL DE EPALZA
}

En el fondo del Archivo Municipal de Elche, recientemente transferido a la Biblioteca Municipal, figura un manuscrito de $21 \times 16 \mathrm{cms}$ y 262 folios no numerados. Tiene por título «El Abecedario Arabe antiguo y Mauritano", al que se le añade "Hallase con algunos coloquios entre un Moro y un Español». Tiene un sello moderno: PROPIEDAD DE P. IBARRA n. ${ }^{\circ} 485$. Debo su conocimiento al Dr. Rafael Navarro Mallabrera, que me informa que los fondos de D. Pedro lbarra procedian en su mayor parte de la desamortización de religiosos de Elche (dominicos y mercedarios).

En realidad, se trata de un cuaderno de un estudioso del siglo XVIII que se puso a aprender el árabe con un magrebí («mauritano»). En la contraportada del libro añade el propietario del cuaderno: «Empesé a escrivirlo y estudiarlo con Cidy Thabet oy dia veinte de enero del año 1768». Es el único dato biográfico que se aprecia en el cuaderno, además de dos comentarios sobre lo difícil que es el árabe y sobre las diferencias entre el español y la pronunciación de valencianos y catalanes, lo que indicaría que el propietario vivía probablemente en zona ilicitana. Los coloquios anunciados en el subtítulo no figuran en el cuaderno, a no ser que se refieran a las frases lexicográficas del método de aprender el árabe.

Ese «método» es muy sencillo y no tiene ninguna relación con la gramática árabe y la forma tradicional como se enseña el árabe en países árabes. Por eso se puede con fundamento pensar que el magrebí era analfabeto y que la metodología la imponía el español. La progresión es guiada por el abecedario o lista de sonidos, tal y como los captaba el español, que pedía al magrebí que le dijera frases o palabras que empezaran por ese sonido. Algunas veces el vocabulario no es ya alfabético, sino temático: saludos, días y meses, frutas, etc. Para cada frase o cada palabra de ese léxico hay una transcripción fonética en letras latinas $y$ una traducción al castellano, mientras que sólo a veces hay una versión escrita en árabe. 
La causa de ese desfase se debe, hay que repetirlo, a que el magrebí no sabía escribir -no se ve ni una sola palabra escrita por él- y que el español tiene que adivinar la escritura árabe, muy penosamente. Se ve que el magrebí no le enseña «árabe antiguo», sino dialectal magrebí. Es probable que sea argelino, porque no se ven expresiones típicamente marroquíes y porque en los ejemplos se cita al Bey (cargo de origen turco, en Argelia y Túnez) y la ciudad de Wahrán (Orán, entonces ocupada por los españoles). Aunque el nombre de Thábit es general en el mundo árabe, hay santuarios de Sidi Thábit particularmente venerados en Túnez y Argelia.

Este cuaderno podría presentar algún interés para estudiosos del árabe dialectal magrebí. Es posible que por la letra y otros indicios pueda en el futuro identificarse a su autor. Pero es interesante, sobre todo, como testimonio del interés por aprender el árabe por parte de numerosos eruditos en España, a fines del XVIII. Esta razonada afición, que tenía muchas causas convergentes, ha sido ya estudiada, pero adquiere un nuevo y específico testimonio con este cuaderno de Elche. 